\title{
Urgences
}

\section{Au moindre coeur de paume...}

\section{Vianney Gallant}

Numéro 11, 3e trimestre 1984

URI : https://id.erudit.org/iderudit/025176ar

DOI : https://doi.org/10.7202/025176ar

Aller au sommaire du numéro

Éditeur(s)

Urgences

ISSN

0226-9554 (imprimé)

1927-3924 (numérique)

Découvrir la revue

Citer ce document

Gallant, V. (1984). Au moindre coeur de paume... Urgences, (11), 71-76.

https://doi.org/10.7202/025176ar

Ce document est protégé par la loi sur le droit d'auteur. L'utilisation des services d'Érudit (y compris la reproduction) est assujettie à sa politique d'utilisation que vous pouvez consulter en ligne.

https://apropos.erudit.org/fr/usagers/politique-dutilisation/
Cet article est diffusé et préservé par Érudit.

Érudit est un consortium interuniversitaire sans but lucratif composé de l'Université de Montréal, l'Université Laval et l'Université du Québec à Montréal. Il a pour mission la promotion et la valorisation de la recherche. https://www.erudit.org/fr/ 
VIANNEY GALLANT 
Au moindre coeur de paume tes doigts d'ombre calcaire

comme le tableau au-delà du vert ton nom croît 
Sur les grandes ailes du terroir

ces chevaux de bois qui circulent en nos têtes

ont grandi

si bien

qu'on retrouve en chaque foyer

l'iris des sorcelleries implicites

où les dieux domestiques ont leur clé

la pleine lune est toujours dansée

dans les ventres mutants

l'encre comme un trop plein de sang demeure autre en dehors du clan

l'alcôve du souvenir et... silence 
Petits cris noctambules

et petits pas à découvert

dense la rue

danse la rue

sur ton arc-en-ciel 
... et du silence en octroyer l'encens...

Tu gicles dans le rêve cette cyprine bleue dont I'attente est taboue petits papiers éreintés d'espoir qui givrent dans le doux temps

On a besoin de ces bourgeons l'aréole du mystère et du jardin couvert ensemencer la mémoire 
Soulèvement

L'Aube

ton feu jusque sur la neige

Engelure

la nuit s'étreint de vivance

Solitude vaillante comme une étoile 